\title{
APPLICATION OF QUANTITATIVE MODELS IN THE ORGANIZATION OF THE FINANCIAL FUNCTION OF AGRICULTURAL ENTERPRISES
}

\author{
Ivan Milojević ${ }^{1}$, Milan Mihajlovićn ${ }^{2}$, Milica Popović3 ${ }^{3}$, Nemanja Pantićc \\ *Corresponding author E-mail: milan.mih83@gmail.com
}

A R T I C L E I N F O
Original Article
Received: 16 April 2020
Accepted: 26 July 2020
doi:10.5937/ekoPolj2003747M
UDC 631.162:338.431

Keywords:

financial function, optimization, agricultural enterprises

JEL: L22, Q19, C61

\begin{abstract}
A B S T R A C T
The role and content of the financial function can be seen through the identification of its tasks. They determine the volume and method of organization of the financial function in agricultural enterprises. Hierarchical priorities of tasks, their volume and complexity, the impact on business efficiency are just some aspects that affect its organization. Multi-criteria optimization methods can be used in choosing the organization and setting the model of job specialization within the organizational structure of the financial function of agricultural enterprises. By applying the individual methods that have been applied so far, not all requirements could be fully covered, so in this paper we applied a hybrid optimization model - DEMATELTOPSIS. The DEMATEL method was used for obtaining the weighting coefficients of the criteria on the basis of which the evaluation of alternatives was performed. The selection of criteria for evaluating the model was based on the analysis of the available literature. Evaluation and selection of models was performed using a multicriteria method - TOPSIS. The paper presents the practical application and sensitivity analysis of the TOPSIS method.
\end{abstract}

(C) 2020 EA. All rights reserved.

1 Ivan Milojević, Ph.D., Full Professor, Ministry of Defence, The Human Resources Sector, Nemanjina 15, 11000 Belgrade, Republic of Serbia, Phone: + 381692702 697, E-mail: drimilojevic@gmail.com, ORCID ID (http://orcid.org/0000-0003-3653-33477)

2 Milan Mihajlović, Ph.D., Assistant Professor, Military Academy, University of Defence, Pavla Jurišića Šturma 33, Belgrade, Republic of Serbia, Phone: +381 643021 951, E-mail: milan.mih83@gmail.com ORCID ID (http://orcid.org/0000-0002-4975-9742)

3 Milica Popović, Assistant, Megatrend University, Bulevar maršala Tolbuhina 8, 11000 Belgrade, Republic of Serbia, Phone: +381 63551 291, E-mail: milica.popovic.edu@ gmail.com, ORCID ID (http://orcid.org/0000-0003-3255-8095)

4 Nemanja Pantić, Ph.D., Teaching Assistant, Universitiy of Kragujevac, Faculty of Hotel management and Tourism in Vrnjačka Banja, Vojvođanska 5A, 36210 Vrnjačka Banja, Republic of Serbia, Phone: +381 602058 758, E-mail: nemanja.pantic@kg.ac.rs, ORCID ID (http://orcid.org/0000-0003-0030-6950) 


\section{Introduction}

The financial function is to some extent an independent whole in achieving its goals (Okunlola et al., 2019). However, it cannot be isolated and act separately because the execution of its tasks depends on cooperation with other business functions of the organization. The financial function in its tasks represents to a certain extent an independent whole, but it cannot exist independently and act separately, but the fulfillment of its tasks is conditioned by cooperation with other business functions of the organization (Vasilev et al, 2019). The execution of the tasks of the financial function of agricultural enterprises can be seen through primary and secondary tasks (Ilić, 2019; Rakić, \& Adamović, 2019). The most common tasks are: obtaining and investing funds and matching them with the period of mobilization and availability of elections due to the specificity of agricultural production (Milašinović et al., 2019). These tasks are complemented by secondary tasks relating to: financial planning, maintaining financial records, liquidating documentation, financial control over the use of funds, depositing money, financial analysis and information, etc (Bolzem, 2015).

Agricultural enterprises seek to obtain rationally used funds, whereby the objective of the financial function is to shape: the purpose of the use of funds, the temporal dimension of use and the expected return on assets, taking into account the potential risk of investment in agricultural production (Zekić, 2015; Savić \& Nešković, 2018). By establishing a functional link between the use and availability of funds, the task of the financial function is primarily reflected in their alignment to ensure the ongoing liquidity and solvency of the business (Ertz et al., 2019).

The establishment of equilibrium is reflected not only in the time availability of use, but also in the functional availability of the source of funds for agricultural production (Krstić et al., 2017; Jolović \& Bobera, 2019; Grbić \& Jovanović, 2020). In order to balance the availability of funds and their sources, a balance must be struck between short-term and long-term sources of funds (Akanbi et al., 2015).

The subject of this paper is precisely the possibility of optimizing the organization of the financial function of the agricultural enterprise using multi-criteria models (Ciutacu \& Chivu, 2014). This aims at proposing a model that can be applied in organizations depending on the qualitative and qualitative characteristics of a particular agricultural enterprise.

Considering the secondary tasks of the financial function that are categorically more pronounced, compared to the primary tasks that are qualitatively more complex, some assumptions are made, which are the starting points of this research

The liquidation of financial documents is implemented before each payment due to the deposit of funds or settlement of liabilities (Vasić, 2015; Simić, Kosumi \& Jialiang, 2019).. In addition, there is ongoing financial supervision over the use of funds, whether the funds are used in the intended volume and structure.

Both cash and non-cash records are required to carry out these tasks, which is certainly different from accounting records. The necessity of these records is reflected in the need 
to familiarize the management with the real state of deposit accounts (not accounting), the status of approved but unused loans, the balance of reserved and non-committed funds, etc (Chomanov et al., 2020).

With such internal data provided, the financial function also obtains external data to provide permanent financial planning which is reflected in the presentation of the required volume of funds, the required time of use of these funds, potential sources and the cost of obtaining funds (Shripathi, K.P. 2018).

\section{Materials and methods}

Within decision theory, there are a number of multi criteria decision making (MCDM) methods that support us in solving the problem of choosing the optimal organization. Each MCDM method is characterized by a specific mathematical apparatus, which is why different methods often result in different results (Bergman \& Lundberg, 2013; Đurković, et al., 2019; Mimović \& Krstić, 2016).

Methodologically, DEMATEL is a multicriteria technique (Alberti et al, 2011; Bobar, et. al., 2015; Durkalić, Furtula \& Borisavljević, 2019; Tang et al., 2020) that is based on decomposing a complex problem into a hierarchy and will be used in this model to derive weighting coefficients on the basis of which the evaluation of alternatives was performed. The TOPSIS method (Yang, et. al., 2008; Tsai, et al., 2010) will be used to rank alternatives based on the criteria obtained, comparing alternatives' distances from ideal solutions. The goal is at the top of the hierarchy, while the criteria, sub-criteria and alternatives are at the lower levels. DEMATEL holds all parts of the hierarchy in the relationship, so it's easy to see how changing one factor affects the other factors

The process of selecting an adequate model of organization of the financial function of an agricultural enterprise starts from the view that there is no universal model of structure, but one must constantly take into account the state of the relevant factors of its configuration (Jing, 2020). Based on the research conducted by Janićijević et al (2019), the criteria for selecting the optimal organization model of Table 1 were selected.

Table 1. Respondents' ratings of QR code for honey

\begin{tabular}{|c|c|l|}
\hline No & $\begin{array}{c}\text { Criterion name and } \\
\text { designation }\end{array}$ & \multicolumn{1}{c|}{ Criterion description } \\
\hline 1. & Technology $\left(C_{1}\right)$ & $\begin{array}{l}\text { Features that increase with the increasing complexity of } \\
\text { technology include: the number of levels in the hierarchy, the } \\
\text { ratio of the number of production and non-production workers, the } \\
\text { number of managers to the total number of employees, the range } \\
\text { of control of senior managers, etc. }\end{array}$ \\
\hline 2. & Personnel $\left(C_{2}\right)$ & $\begin{array}{l}\text { Provision and availability of qualified personnel for financial } \\
\text { functions in the agricultural sector. }\end{array}$ \\
\hline 3. & $\begin{array}{c}\text { The size of the } \\
\text { organization }\left(C_{3}\right)\end{array}$ & $\begin{array}{l}\text { The growth of the organizational structure equally captures the } \\
\text { dimensions of the overall structure. Consequential changes include } \\
\text { the degree of formalization and the degree of decentralization. }\end{array}$ \\
\hline
\end{tabular}




\begin{tabular}{|c|c|l|}
\hline No & $\begin{array}{c}\text { Criterion name and } \\
\text { designation }\end{array}$ & \multicolumn{1}{c|}{ Criterion description } \\
\hline 4. & Life cycle stages $\left(C_{4}\right)$ & $\begin{array}{l}\text { It is not an independent variable, i.e. there is no automatism of } \\
\text { the transition from phase to phase that compels certain behavior, } \\
\text { but rather there is a certain behavior that can be identified as } \\
\text { characteristic at some stage of the life cycle. }\end{array}$ \\
\hline 5. & The environment $\left(C_{5}\right)$ & $\begin{array}{l}\text { The characteristics of the environment that most affect } \\
\text { the Organization are heterogeneity, variability-stability, } \\
\text { interdependence. The variability of the environment puts further } \\
\text { pressure on the decision-making capacity at the top. }\end{array}$ \\
\hline 6. & Funding $\left(C_{6}\right)$ & $\begin{array}{l}\text { Possibility of financing the financial function and providing the } \\
\text { resources needed to carry out financing in agribusinesses. }\end{array}$ \\
\hline
\end{tabular}

Source: Janićijević et. Al, 2019

A total of five models of organization of the financial function of an agricultural enterprise were considered: $A_{1}$. centralization, $A_{2}$. division of labor or specialization, $A_{3}$. unit grouping or departmentalisation, $\mathrm{A}_{4}$. distribution of authority or decentralization, $\mathrm{A}_{5}$. network. Ten experts participated in the model testing process. Expert decisions were used to derive the criterion weights. Weight coefficients were obtained using the DEMATEL method.

Testing and model selection was conducted through two phases. In the first phase, the criterion was selected and the weights of the criteria were defined using the DEMATEL method. In the second phase, the TOPSIS method selected the optimal model(Falagario, 2012).

In the first step of the DEMATEL method, Saaty's scale was used to compare the criteria (Saaty, 1980). The scale shown was used to derive the offset matrices for the criteria $Z=\left[Z_{i j}\right]$. Since ten experts participated in the study, a total of ten averaged criteria matrices were obtained after implementation. Aggregation of expert opinions

was performed using the term $z_{i j}=\sqrt[k]{\prod_{i=1}^{k} z_{i j}^{e}}$ and is shown in Table 2.

Table 2. Aggregation of expert opinions

\begin{tabular}{|c|c|c|c|c|c|c|}
\hline & $\mathrm{C}_{1}$ & $\mathrm{C}_{2}$ & $\mathrm{C}_{3}$ & $\mathrm{C}_{4}$ & $\mathrm{C}_{5}$ & $\mathrm{C}_{6}$ \\
\hline $\mathrm{C}_{1}$ & 1,00 & 0,56 & 2,28 & 3,11 & 0,38 & 7,44 \\
\hline $\mathrm{C}_{2}$ & 2,09 & 1,00 & 3,51 & 3,03 & 3,00 & 5,01 \\
\hline $\mathrm{C}_{3}$ & 0,44 & 0,32 & 1,00 & 1,25 & 3,14 & 2,20 \\
\hline $\mathrm{C}_{4}$ & 0,32 & 0,33 & 0,80 & 1,00 & 3,09 & 1,25 \\
\hline $\mathrm{C}_{5}$ & 2,61 & 0,49 & 0,33 & 0,29 & 1,00 & 1,37 \\
\hline $\mathrm{C}_{6}$ & 0,13 & 0,18 & 0,43 & 0,82 & 0,73 & 1,00 \\
\hline
\end{tabular}

Source: Authors' calculations 
Table 2. is the starting point for obtaining the initial normalized direct link matrix

$$
D=\left[\begin{array}{cccc}
d_{11} & d_{12} & \ldots & d_{1 n} \\
d_{21} & d_{22} & \ldots & d_{2 n} \\
\ldots & \ldots & \ldots & \ldots \\
d_{n 1} & d_{n 2} & \ldots & d_{n n}
\end{array}\right]
$$

Based on expressions representing the elements of the matrix $d_{i j}=\frac{\boldsymbol{Z}_{i j}}{R} \quad$ and $R=\max \left(\sum_{j=1}^{n} z_{i j}\right)$ we get the matrix, $D$ (Pamučar et al., 2018), Table 3. After obtaining the Expert Opinion Aggregation Matrix (Table 2), the normalized direct link matrix is calculated using the above expressions $D$.

Table 3. Aggregation of expert opinions

\begin{tabular}{|c|c|c|c|c|c|c|}
\hline & $\mathrm{C}_{1}$ & $\mathrm{C}_{2}$ & $\mathrm{C}_{3}$ & $\mathrm{C}_{4}$ & $\mathrm{C}_{5}$ & $\mathrm{C}_{6}$ \\
\hline $\mathrm{C}_{1}$ & 0,06 & 0,03 & 0,13 & 0,18 & 0,02 & 0,42 \\
\hline $\mathrm{C}_{2}$ & 0,12 & 0,06 & 0,20 & 0,17 & 0,17 & 0,28 \\
\hline $\mathrm{C}_{3}$ & 0,02 & 0,02 & 0,06 & 0,07 & 0,18 & 0,12 \\
\hline $\mathrm{C}_{4}$ & 0,02 & 0,02 & 0,05 & 0,06 & 0,18 & 0,07 \\
\hline $\mathrm{C}_{5}$ & 0,15 & 0,03 & 0,02 & 0,02 & 0,06 & 0,08 \\
\hline $\mathrm{C}_{6}$ & 0,01 & 0,01 & 0,02 & 0,05 & 0,04 & 0,06 \\
\hline
\end{tabular}

Source: Authors' calculations

Based on the elements of the matrix $D$ and by applying the expression $T=\lim _{m \rightarrow \infty}\left(D+D^{2}+\ldots+D^{m}\right)=\sum_{m=1}^{\infty} D^{i}$ where is

$$
\begin{aligned}
\sum_{m=1}^{\infty} D^{i} & =D+D^{2}+\ldots+D^{m}= \\
& =D\left(I+D^{1}+D^{2}+\ldots+D^{m-1}\right) \\
& =D(I-D)^{-1}(I-D)\left(I+D^{1}+D^{2}+\ldots+D^{m-1}\right) \\
& =D(I-D)^{-1}\left(I-D^{m}\right) \\
& =D(I-D)^{-1}
\end{aligned}
$$

the elements of the matrix of total impact $\mathrm{T}$ are determined. The total relation matrix is shown in Table 4. 
Table 4. Total relation matrix

\begin{tabular}{|c|c|c|c|c|c|c|}
\hline & $\mathrm{C}_{1}$ & $\mathrm{C}_{2}$ & $\mathrm{C}_{3}$ & $\mathrm{C}_{4}$ & $\mathrm{C}_{5}$ & $\mathrm{C}_{6}$ \\
\hline $\mathrm{C}_{1}$ & 0,1105 & 0,0561 & 0,1952 & 0,2708 & 0,1473 & 0,5705 \\
\hline $\mathrm{C}_{2}$ & 0,2125 & 0,0995 & 0,2971 & 0,2961 & 0,3387 & 0,5112 \\
\hline $\mathrm{C}_{3}$ & 0,0732 & 0,0385 & 0,0984 & 0,1195 & 0,2509 & 0,2146 \\
\hline $\mathrm{C}_{4}$ & 0,0703 & 0,0369 & 0,0848 & 0,1038 & 0,2424 & 0,1561 \\
\hline $\mathrm{C}_{5}$ & 0,1894 & 0,0471 & 0,0689 & 0,0847 & 0,1147 & 0,2086 \\
\hline $\mathrm{C}_{6}$ & 0,0274 & 0,0171 & 0,0360 & 0,0709 & 0,0708 & 0,0971 \\
\hline
\end{tabular}

Source: Authors' calculations

To make a diagram of the cause-and-effect relationships, using the expression $D_{i}=\sum_{i=1}^{n} t_{i j}, i=1,2, \ldots, n$ and $R_{i}=\sum_{j=1}^{m} t_{i j}, j=1,2, \ldots, m$ we determined the sum of the direct and indirect interactions of the factors (Pamučar et al., 2018) (Table 5).

Table 5. Sum of direct (D) and indirect (R) effects of factors

\begin{tabular}{|c|c|c|}
\hline & $D$ & $R$ \\
\hline$C_{1}$ & 1,35 & 0,68 \\
\hline$C_{2}$ & 1,76 & 0,30 \\
\hline$C_{3}$ & 0,80 & 0,78 \\
\hline$C_{4}$ & 0,69 & 0,95 \\
\hline$C_{5}$ & 0,71 & 1,16 \\
\hline$C_{6}$ & 0,32 & 1,76 \\
\hline
\end{tabular}

Source: Authors' calculations

Based on the limit value $(\alpha) \alpha=\frac{\sum_{i=1}^{n} \sum_{j=1}^{n}\left[t_{i j}\right]}{N}$ (Pamučar et al., 2018)the average of the elements of the matrix $T$ is calculated and a diagram of cause and effect relationships is drawn up in order to visually represent the complex relationships, Figure 1. 
Figure 1. Diagram of causal relationships

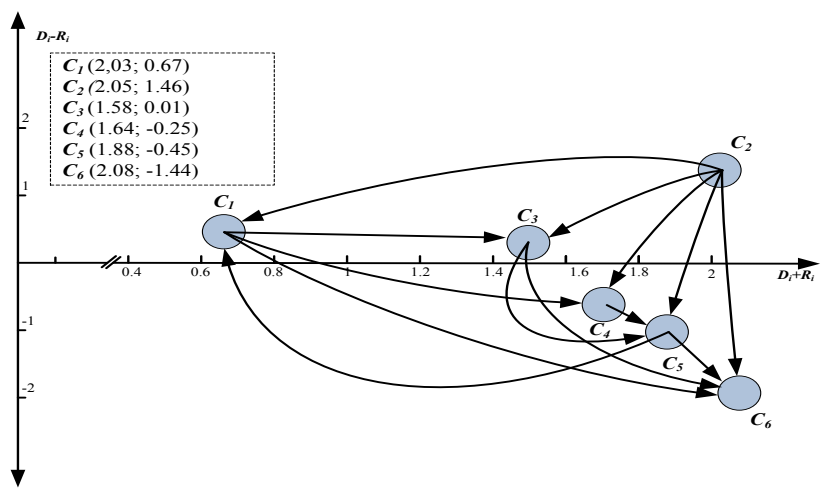

Source: Authors' calculations

The presented diagram gives us information about the importance of factors on the system and the interaction of the presented factors. Factors of the matrix of the total relation whose value is greater than the limit value $(\alpha=0.16)$ are chosen for the purpose of showing cause and effect relationships.

After determining the relationship between criteria (factors) by applying the expression $W_{i}=\sqrt{\left(G_{i}+R_{i}\right)^{2}+\left(G_{i}-R_{i}\right)^{2}}$ and $w_{i}=\frac{W_{i}}{\sum_{i=1}^{n} W_{i}}$ criteria weights are determined, Table 6.

Table 6. Criteria weight coefficients $(w)$

\begin{tabular}{|c|c|c|c|c|}
\hline & $\mathrm{D}+\mathrm{R}$ & $\mathrm{D}-\mathrm{R}$ & $W$ & $w$ \\
\hline $\mathrm{C}_{1}$ & 2,03 & 0,67 & 2,14 & 0,173 \\
\hline $\mathrm{C}_{2}$ & 2,05 & 1,46 & 2,52 & 0,204 \\
\hline $\mathrm{C}_{3}$ & 1,58 & 0,01 & 1,58 & 0,128 \\
\hline $\mathrm{C}_{4}$ & 1,64 & $-0,25$ & 1,66 & 0,134 \\
\hline $\mathrm{C}_{5}$ & 1,88 & $-0,45$ & 1,93 & 0,156 \\
\hline $\mathrm{C}_{6}$ & 2,08 & $-1,44$ & 2,53 & 0,205 \\
\hline
\end{tabular}

Source: Authors' calculations

Weighting coefficients of criteria, pores of initial decision matrix

$$
R=\begin{gathered}
A_{1} \\
A_{2} \\
\cdot \\
A_{3}
\end{gathered}\left[\begin{array}{cccc}
r_{11} & r_{12} & \ldots & r_{1 m} \\
r_{21} & r_{22} & \ldots & r_{2 m} \\
\ldots & \ldots & \ldots \\
r_{n 1} & r_{n 2} & \ldots & r_{n m}
\end{array}\right], \text { represent the input parameters for the implementation of }
$$


the TOPSIS method, Table 7

Table 7. Initial decision matrix

\begin{tabular}{|c|c|c|c|c|c|c|}
\hline & $\mathrm{C}_{1}$ & $\mathrm{C}_{2}$ & $\mathrm{C}_{3}$ & $\mathrm{C}_{4}$ & $\mathrm{C}_{5}$ & $\mathrm{C}_{6}$ \\
\hline $\mathrm{A}_{1}$ & 2,11 & 3,03 & 0,42 & 0,22 & 0,20 & 1,05 \\
\hline $\mathrm{A}_{2}$ & 1,83 & 2,87 & 0,33 & 0,28 & 0,16 & 1,20 \\
\hline $\mathrm{A}_{3}$ & 2,60 & 4,11 & 0,51 & 0,15 & 0,08 & 0,92 \\
\hline $\mathrm{A}_{4}$ & 1,68 & 2,43 & 0,23 & 0,30 & 0,22 & 1,53 \\
\hline $\mathrm{A}_{5}$ & 2,23 & 2,75 & 0,47 & 0,17 & 0,11 & 1,13 \\
\hline$w_{i}$ & 0,173 & 0,204 & 0,128 & 0,134 & 0,156 & 0,205 \\
\hline
\end{tabular}

Source: Authors' calculations

After calculating the criterion weights $\left(w_{i}\right)$ After the calculation of the weights, the conditions for evaluation and selection of the optimal alternative using the TOPSIS

method were met. By applying the expression of the criteria criters $x_{i j}=\frac{r_{i j}}{\sqrt{\sum_{i=1}^{n} r_{i j}^{2}}}$

the elements of the initial decision matrix are normalized (Pamučar et al., 2018).

By multiplying the normalized elements of the matrix $X=\begin{aligned} & A_{1} \\ & A_{2} \\ & A_{3}\end{aligned}\left[\begin{array}{cccc}x_{11} & x_{12} & \ldots & x_{1 m} \\ x_{21} & x_{22} & \ldots & x_{2 m} \\ \ldots & \ldots & \ldots \\ x_{n 1} & x_{n 2} & \ldots & x_{n m}\end{array}\right]$

with weight coefficients $\left(w_{i}\right)$ we get an aggravated noramlized matrix

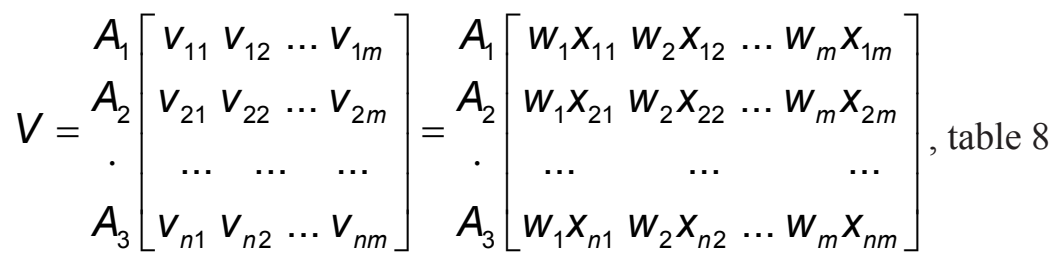

Table 8. Difficult normalized matrix

\begin{tabular}{|c|c|c|c|c|c|c|}
\hline & $\mathrm{C}_{1}$ & $\mathrm{C}_{2}$ & $\mathrm{C}_{3}$ & $\mathrm{C}_{4}$ & $\mathrm{C}_{5}$ & $\mathrm{C}_{6}$ \\
\hline $\mathrm{A}_{1}$ & 0,077 & 0,089 & 0,059 & 0,057 & 0,086 & 0,081 \\
\hline $\mathrm{A}_{2}$ & 0,067 & 0,085 & 0,047 & 0,073 & 0,069 & 0,093 \\
\hline $\mathrm{A}_{3}$ & 0,095 & 0,121 & 0,072 & 0,039 & 0,034 & 0,071 \\
\hline $\mathrm{A}_{4}$ & 0,062 & 0,072 & 0,032 & 0,078 & 0,095 & 0,118 \\
\hline $\mathrm{A}_{5}$ & 0,082 & 0,081 & 0,066 & 0,044 & 0,047 & 0,087 \\
\hline
\end{tabular}


By defining ideal solutions and separating alternatives from ideal solutions by

expression $S_{i}^{*}=\sqrt{\sum_{j=1}^{m}\left(v_{i j}-v_{j}^{*}\right)^{2}}, i=1, \ldots, n$ and $S_{i}^{-}=\sqrt{\sum_{j=1}^{m}\left(v_{i j}-v_{j}^{-}\right)^{2}}, i=1, \ldots, n$

we obtain the final ranking of alternatives, which is shown in Table 9.

Table 9. Final ranking of alternatives

\begin{tabular}{|c|c|c|c|c|}
\hline & $\mathrm{S}_{\mathrm{i}}^{+}$ & $\mathrm{S}_{\mathrm{i}}^{-}$ & $\mathrm{Q}_{\mathrm{i}}$ & ranking \\
\hline $\mathrm{A}_{1}$ & 0,0581 & 0,0661 & 0,5321 & 2 \\
\hline $\mathrm{A}_{2}$ & 0,0642 & 0,0564 & 0,4679 & 3 \\
\hline $\mathrm{A}_{3}$ & 0,0858 & 0,0717 & 0,4555 & 4 \\
\hline $\mathrm{A}_{4}$ & 0,0717 & 0,0858 & 0,5445 & 1 \\
\hline $\mathrm{A}_{5}$ & 0,0784 & 0,0458 & 0,3686 & 5 \\
\hline
\end{tabular}

Source: Authors' calculations

Applying the hybrid model, or a combination of DEMATEL and TOPSIS method, we get the solution to be the most optimal model, under number 4, which has the highest ranking among all alternatives. However, it should be emphasized that in this way the result obtained is only a possible variant, since the application of multicriteria optimization does not mean a rigorous solution, but an opportunity that can only be verified by the comparison of several different methods and scales of estimation.

The advantage of using multi-criteria optimization models is the possibility of software support in the specific example of using Visula Basic for Applications program, where after determining the weight of the criteria and inserting data, it is relatively easy to check the ranking alternatives with graphical representation.

Table 10. Calculating the rank of the proposed models in the software

\begin{tabular}{|c|c|c|c|c|c|c|}
\hline \multirow{2}{*}{ Alternatives } & \multicolumn{6}{|c|}{ Criteria (criterion weights) } \\
\cline { 2 - 7 } & $\mathrm{K} 1$ & $\mathrm{~K} 2$ & $\mathrm{~K} 3$ & $\mathrm{~K} 4$ & $\mathrm{~K} 5$ & $\mathrm{~K} 6$ \\
\cline { 2 - 7 } & 0.173 & 0.204 & 0.128 & 0.134 & 0.156 & 0.205 \\
\hline model 1 & 2.11 & 3.03 & 0.42 & 0.22 & 0.20 & 1.05 \\
\hline model 2 & 1.83 & 2.87 & 0.33 & 0.28 & 0.16 & 1.20 \\
\hline model 3 & 2.60 & 4.11 & 0.51 & 0.15 & 0.08 & 0.92 \\
\hline model 4 & 1.68 & 2.43 & 0.23 & 0.30 & 0.22 & 1.53 \\
\hline model 5 & 2.23 & 2.75 & 0.47 & 0.17 & 0.11 & 1.13 \\
\hline
\end{tabular}

Source: Authors' calculations 
Table 11. The final rank of the alternatives

\begin{tabular}{|c|c|}
\hline Criterion function value $F(x)$ & Final rank \\
\hline 0.5321 & 2 \\
\hline 0.4679 & 3 \\
\hline 0.4555 & 4 \\
\hline 0.5445 & 1 \\
\hline 0.3686 & 5 \\
\hline
\end{tabular}

Source: Authors' calculations

Figure 3. Final ranking diagram of alternatives

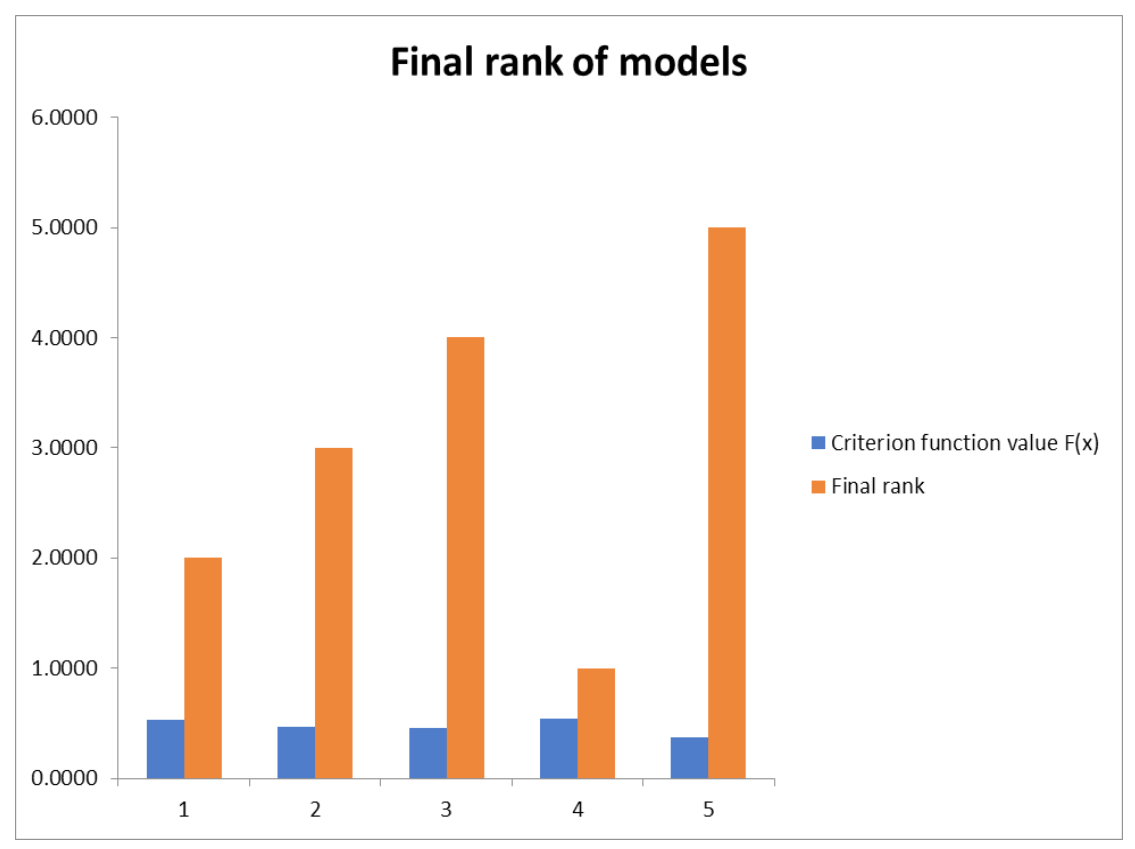

Source: Authors' calculations

When applying the MCDM ranking, the alternative changes with the change in the weight coefficients of the criteria, that is, the relative importance we attribute to the particular criteria (Mongollon et al., 2020). Therefore, it is necessary to perform a sensitivity analysis of the solution. 
Table 12. Sensitivity analysis

\begin{tabular}{|c|c|c|c|c|c|c|c|c|c|c|c|}
\hline & \multicolumn{6}{|c|}{ Criterion weight coefficient } & \multicolumn{5}{|c|}{ Criterion function value } \\
\hline & K1 & $\mathbf{K} 2$ & K3 & K4 & K5 & K6 & M 1 & M 2 & M 3 & M 4 & M 5 \\
\hline Variant 1 & 0.50 & 0.10 & 0.10 & 0.10 & 0.10 & 0.10 & 0.500 & 0.288 & 0.698 & 0.302 & 0.534 \\
\hline Variant 2 & 0.40 & 0.12 & 0.12 & 0.12 & 0.12 & 0.12 & 0.531 & 0.377 & 0.587 & 0.413 & 0.477 \\
\hline Variant 3 & 0.30 & 0.14 & 0.14 & 0.14 & 0.14 & 0.14 & 0.553 & 0.437 & 0.518 & 0.482 & 0.438 \\
\hline Variant 4 & 0.20 & 0.16 & 0.16 & 0.16 & 0.16 & 0.16 & 0.569 & 0.486 & 0.464 & 0.536 & 0.408 \\
\hline Variant 5 & 0.10 & 0.50 & 0.10 & 0.10 & 0.10 & 0.10 & 0.423 & 0.337 & 0.704 & 0.296 & 0.266 \\
\hline Variant 6 & 0.12 & 0.40 & 0.12 & 0.12 & 0.12 & 0.12 & 0.465 . & 0.383 & 0.625 & 0.375 & 0.308 \\
\hline Variant 7 & 0.14 & 0.30 & 0.14 & 0.14 & 0.14 & 0.14 & 0.515 & 0.436 & 0.544 & 0.456 & 0.353 \\
\hline Variant 8 & 0.16 & 0.20 & 0.16 & 0.16 & 0.16 & 0.16 & 0.561 & 0.485 & 0.471 & 0.529 & 0.392 \\
\hline Variant 9 & 0.10 & 0.10 & 0.50 & 0.10 & 0.10 & 0.10 & 0.656 & 0.386 & 0.747 & 0.253 & 0.720 \\
\hline Variant 10 & 0.12 & 0.12 & 0.40 & 0.12 & 0.12 & 0.12 & 0.638 & 0.411 & 0.669 & 0.331 & 0.646 \\
\hline Variant 11 & 0.14 & 0.14 & 0.30 & 0.14 & 0.14 & 0.14 & 0.612 & 0.446 & 0.578 & 0.422 & 0.553 \\
\hline Variant 12 & 0.16 & 0.16 & 0.20 & 0.16 & 0.16 & 0.16 & 0.582 & 0.486 & 0.482 & 0.518 & 0.441 \\
\hline Variant 13 & 0.10 & 0.10 & 0.10 & 0.50 & 0.10 & 0.10 & 0.491 & 0.753 & 0.225 & 0.776 & 0.219 \\
\hline Variant 14 & 0.12 & 0.12 & 0.12 & 0.40 & 0.12 & 0.12 & 0.510 & 0.690 & 0.292 & 0.708 & 0.268 \\
\hline Variant 15 & 0.14 & 0.14 & 0.14 & 0.30 & 0.14 & 0.14 & 0.536 & 0.612 & 0.364 & 0.636 & 0.327 \\
\hline Variant 16 & 0.16 & 0.16 & 0.16 & 0.20 & 0.16 & 0.16 & 0.565 & 0.525 & 0.432 & 0.568 & 0.385 \\
\hline Variant 17 & 0.10 & 0.10 & 0.10 & 0.10 & 0.50 & 0.10 & 0.799 & 0.561 & 0.183 & 0.817 & 0.248 \\
\hline Variant 18 & 0.12 & 0.12 & 0.12 & 0.12 & 0.40 & 0.12 & 0.755 & 0.551 & 0.248 & 0.753 & 0.278 \\
\hline Variant 19 & 0.14 & 0.14 & 0.14 & 0.14 & 0.30 & 0.14 & 0.691 & 0.533 & 0.327 & 0.673 & 0.322 \\
\hline Variant 20 & 0.16 & 0.16 & 0.16 & 0.16 & 0.20 & 0.16 & 0.605 & 0.507 & 0.420 & 0.580 & 0.381 \\
\hline Variant 21 & 0.10 & 0.10 & 0.10 & 0.10 & 0.10 & 0.50 & 0.345 & 0.471 & 0.260 & 0.740 & 0.363 \\
\hline Variant 22 & 0.12 & 0.12 & 0.12 & 0.12 & 0.12 & 0.40 & 0.411 & 0.479 & 0.326 & 0.674 & 0.375 \\
\hline Variant 23 & 0.14 & 0.14 & 0.14 & 0.14 & 0.14 & 0.30 & 0.485 & 0.488 & 0.389 & 0.611 & 0.388 \\
\hline Variant 24 & 0.16 & 0.16 & 0.16 & 0.16 & 0.16 & 0.20 & 0.554 & 0.496 & 0.439 & 0.561 & 0.399 \\
\hline
\end{tabular}

Source: Authors' calculations

Table 11 shows the different options for ranking alternatives depending on the change in weight criteria. 
Figure 4. Graph of sensitivity analysis

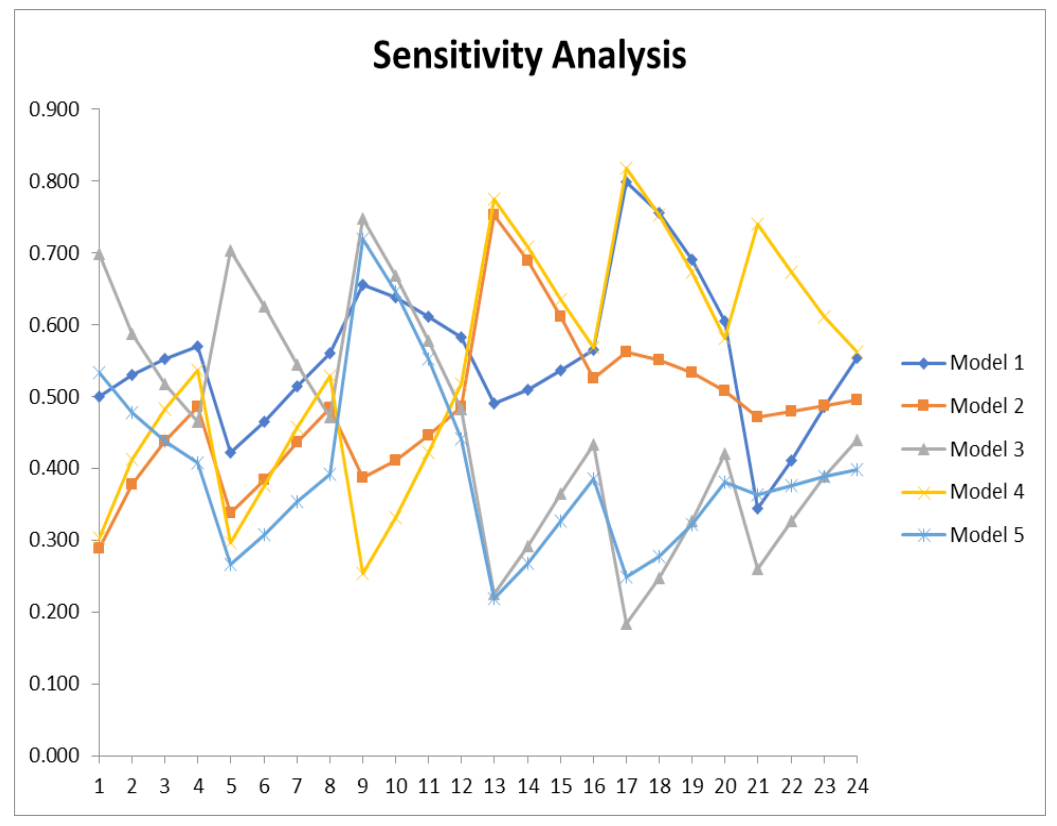

Source: Authors' calculations

Sensitivity analysis was performed to assess how changes in the weights assigned to the criteria would change the range of alternatives. Scenarios 1 to 24, which correspond to different weights assigned to each criterion, and which represent different priorities given to the criteria are shown in Figure 4.The obtained results show that assigning different weights (priorities) to the criteria leads to different ranks, ie. that the model is sensitive to these weights.

However, the sensitivity of the VKO method to changes in the weight coefficients of the criteria is not sufficient data on the basis of which we can draw a conclusion about the reliability of the results given by the VKO method. Comparative analyzes of authors (Rodrigues et al., 2014; Anojkumar et al., 2014; Liu et al., 2013; Wang, and Tzeng, 2012) can be presented in the literature, who try to discover those characteristics of the choice problem that condition equality, ie differences in the solutions of individual VKO methods. However, the same choice that suggests several methods is not a sufficient guarantee of rationality and quality of the obtained solution.

\section{Conclusions}

This paper presents the implementation of the hybrid DEMATEL - TOPSIS model in the decision - making process on the choice of the model of organization of the financial function in agriculture enterprises. The DEMATEL method was used to get the weighting coefficients of the criteria which served for the evaluation of alternatives. The criteria for selecting the model evaluation were made based on the analysis of the available literature. Model estimation and selection were performed using the multi- 
critical TOPSIS method. The paper presents practical applications and sensitivity analysis of the TOPSIS method.

The organization of the financial function is one of the most important elements and affects on the success of the business of agricultural enterprises. It depends on the size, ie the scope of work of the financial function, organizational structure and the type and size of agricultural enterprises. Previous research has identified two basic forms of organization in the European and Anglo-Saxon conceptions. The European conception is based on the classical principles of organization of the authoritative system, while the Anglo-Saxon defines the division of decision making in the form of rights and responsibilities. It occupies one of the five key places in the functional scheme, which certainly differs depending on the factors we have analyzed in the paper. Although the financial function with its tasks is to a certain extent an independent function, it exists in cooperation with other segments of the business entity by providing support for the realization of their activities. In this regard, the proposed model allows us to choose the organizational structure of the financial function, depending on the potentials available and the requirements that lie ahead.

\section{Conflict of interests}

The authors declare no conflict of interest.

\section{References}

1. Akanbi, O.G., Salami, O., \& Awodol, J.G. (2015). Quantitative methods in the designs of organizations: a model and a real world application. Technical Journal, 9(2), 121-127.

2. Alberti, M., Ciurana, J., Rodriguez, C., \& Ozel, T. (2011). Design of a decision support system for machine tool selection based on machine characteristics and performance tests. Journal of Intelligent Manufacturing, 22(2), 263-277. doi: https://doi.org/10.1007/s10845-009-0286-6

3. Bergman, M.A., \& Lundberg, S. (2013). Tender evaluation and supplier selection methods in public procurement. Journal of Purchasing \& Supply Management, 19(2), 73-83. doi: https://doi.org/10.1016/J.PURSUP.2013.02.003

4. Bobar, V., Mandic, K., Delibasic, B., \& Suknovic, M. (2015). An Integrated Fuzzy Approach to Bidder Selection in Public Procurement: Serbian Government Case Study. Acta Polytechnica Hungarica, 12(2), 193-211. doi: https://doi.org/10.12700/ APH.12.2.2015.2.12

5. Bolzem, B. (2015). A new integrative model on trust in organizations: A quantitative approach for application in strategic management. Proceedings of the International Conference on Intellectual Capital, Knowledge Management and Organisational Learning, ICICKM. 
6. Ciutacu, C., \& Chivu, L. (2014). About Agrarian structures and economic advantages. Procedia Economics and Finance, 8, 182-186. doi: https://doi. org/10.1016/S2212-5671(14)00079-3

7. Chomanov, U., Temirbekov, N.M., Kenenbay, G.S., Tultabayeva, T.C., Omirzhanova, B.C., \& Tultabayev, M.C. (2020) Reduction interpolation function for determining the rheological properties of bile in farm animals to increase the entrepreneurial activity of the agricultural sector. Academy of Entrepreneurship Journal, 26(1), 365-375.

8. Durkalić, D., Furtula, S., \& Borisavljević, K. (2019). Rangiranje perfomansi turističkog tržišta u zemljama EMU - rezultati PROMETHEE - GAIA pristupa. Hotel and Tourism Management 7(2), 67-76. doi: https://doi.org/10.5937/ menhottur1902067D

9. Đurković, V., Radosavljević, M., \& Stanković, R. (2019). Primena AHP metode u određivanju značaja primene savremenih bankarskih proizvoda na uspešnost poslovanja banaka. Oditor, 5(1), 70-80. [in English: Đurković, V., Radosavljević, M., \& Stanković, R. (2019). Application of the 'AHP' method in determining the importance of the application of modern banking products to the performance of banks. Oditor, 5(1), 70-80]. doi: https://doi.org/10.5937/Oditor1901069D

10. Ertz, M., Leblanc-Proulx, S., Sarigollu, E., \& Morin, V. (2019). Advancing quantitative rigor in the circular economy literature: New methodology for product lifetime extension business models. Resources conservation and recycling, 4(1), 145-160. doi: https://doi.org/10.1016/j.resconrec.2019.104437

11. Falagario, M., Sciancalepore, F., Costantino, N., \& Pietroforte, R. (2012). Using a DEA-cross efficiency approach in public procurement tenders. European Journal of Operational Research, 218, 523-529. doi: https://doi.org/10.1016/j.ejor.2011.10.031

12. Grbić, M., \& Jovanović, D. (2020). Komparativni finansijski sistemi - implikacije za ekonomski rast. Oditor, 6(1), 49-65. [in English: Grbić, M., \& Jovanović, D. (2020). Comparative financial systems: Implications for economic growth. Oditor, 6(1), 49-65]. doi: https://doi.org/10.5937/Oditor2001046G

13. Ilić, B. (2019). Cena zemlje kao faktor održivog razvoja. Održivi razvoj, 1(2), 7-16. [in English: Ilić, B. (2019). Land price as a factor of sustainable development. Održivi razvoj, 1(2), 7-16]. doi: https://doi.org/10.5937/OdrRaz1902007I

14. Janićijević, N., Bogićević Milikić, B., Petković, M., \& Aleksić Mirić, A. (2019). Organizacija. Beograd: CID, Ekonomski fakultet.

15. Jing, Z. (2020). Corn Amino Acid Nutrition and Economic Benefits of Agricultural Finance. Archivos latinoamericanos de nutricion, 70(2), 695-703.

16. Jolović, I., \& Bobera, D. (2019). Analiza uloge projektnog menadžera u upravljanju istraživačko-razvojnim projektom. Oditor, 5(3), 38-52. [in English: Jolović, I., \& Bobera, D. (2019). Analysis of the project manager's role in the research and development projects. Oditor, 5(3), 38-52]. doi: https://doi.org/10.5937/ Oditor1903038J 
17. Krstić, S.L., Savić-Gligić, A.P., \& Gligić-Dumonjić, J P. (2017). Mogućnost upravljanja rizikom portfolija hartija od vrednosti. Vojno delo, 69(6), 374-383. doi: https://doi.org/10.5937/vojdelo1706374K

18. Milašinović, M., Knežević, S., \& Mitrović, A. (2019). Bankruptcy forecasting of hotel companies in the Republic of Serbia using Altman's Z-score model. Hotel and Tourism Mangement, 7(2), 87-95. doi: https://doi.org/10.5937/menhottur1902087M

19. Mimović, P. \& Krstić, A. (2016). Application of Multi-Criteria Analysis in the Public Procurement Process. Optimization Economic Themes, 54(1), 103-128, doi: https://doi.org/10.1515/ethemes-2016-0006

20. Mogollon, M.R., Jara, A.F., Contreras, C., \& Zoffoli, J.P. (2020). Quantitative and qualitative VIS-NIR models for early determination of internal browning in 'Cripps Pink' apples during cold storage. Postharvest Biology and Technology, 5(9), 256268. doi: https://doi.org/10.1016/j.postharvbio.2019.111060

21. Okunlola, F.A., Osuma, G.O., \& Omankhanlen, E.A. (2019). Agricultural finance and economic growth: Evidence from Nigeria. Business: Theory and Practice, 20(3), 467-475. doi: https://doi.org/10.3846/btp.2019.43

22. Pamučar, D., Pejcic-Tarle S., \& Parezanovic, T. (2018). New hybrid multicriteria decision-making DEMATEL-MAIRCA model: sustainable selection of a location for the development of multimodal logistics centre. Economic ResearchEkonomska Istrazivanja, 31(1), 1641-1665. doi: https://doi.org/10.1080/133167 7X.2018.1506706

23. Rakić, S., \& Adamović, V. (2019). Poslovna etika u funkciji uspešnog poslovanja savremenih kompanija. Oditor, 5(2), 42-57. [in English: Rakić, S., \& Adamović, V. (2019). Business ethics in the function of successful business operations of modern companies. Oditor, 5(2), 42-57]. doi: https://doi.org/10.5937/Oditor1902043R

24. Saaty, T. (1980). The Analytic Hierarchy Process. McGraw-Hill, New York

25. Savić, V., \& Nešković, S. (2018). The effect of the agrarian reform on the development of cultural activities in the Republic of Cuba. Economics of Agriculture, 65(3), 971984. doi: https://doi.org/10.5937/ekoPolj1803971S

26. Simić, N., Kosumi, T., \& Jialiang, Y. (2019). Regulatorni instrumenti održivog razvoja. Održivi razvoj, 1(1), 15-26. [in English: Simić, N., Kosumi, T., \& Jialiang, Y. (2019). Sustainable development regulatory instruments. Održivi razvoj, 1 (1), 15-26]. doi: https://doi.org/10.5937/OdrRaz1901017S

27. Shripathi, K.P. (2018). Trends in Agricultural Finance in India. Asian Journal of Research in Banking and Finance, 8(1), 57-63. doi: https://doi.org/10.5958/22497323.2018.00006.8

28. Tang, L., Wang, H., Li, L., Yang, K., \& Mi, Z. (2020). Quantitative models in emission trading system research: A literature review. Renewable and Sustainable Energy Reviews, 8(4), 457-462. doi: https://doi.org/10.1016/j.rser.2020.110052 
29. Tsai, J.P., Cheng, H.Y., Wang, S.Y., \& Kao, Y.C. (2010). Multi-criteria decision making method for selection of machine tool. Proceedings of IEEE International Symposim on Computer Communication Control and Automation (3CA), 2, 49-52.

30. Vasić, Z. (2015). Poreska kontrola uslov funkcionisanja budžetskog sistema. Akcionarstvo, 21(1), 5-22.

31. Vasilev, D., Cvetković, D., \& Grgur, A. (2019). Detection of fraudulent actions in the financial statements with particular emphasis on hotel companies. Hotel and Tourism Management, 7(1), 115-125. doi: https://doi.org/10.5937/ menhottur1901115V

32. Yang, J.L., Chiu, HN, Tzeng, G.H., \& Yeh, R.H. (2008). Vendor selection by integrated fuzzy MCDM techniques with independent and interdependent relationships. Information Sciences, 178, 4166-4183. doi: https://doi.org/10.1016/j. ins.2008.06.003

33. Zekić, M. (2015). Kontrola i revizije u javnom sektoru. Akcionarstvo, 21(1), 2334. [in English: Zekić, M. (2015). Public sector controls and audits. Akcionarstvo, 21(1), 23-34]. 